\title{
Impact of climate and moonlight on a venomous mammal, the Javan slow loris (Nycticebus javanicus Geoffroy, 1812)
}

\author{
Eva Johanna Rode-Margono ${ }^{1}, \mathrm{~K}$. Anne-Isola Nekaris ${ }^{1,2}$ \\ ${ }^{1}$ Oxford Brookes University, Gipsy Lane, Headington, Oxford OX3 OBP, UK \\ ${ }^{2}$ E-mail: anekaris@brookes.ac.uk
}

Keywords: activity, environmental factors, humidity, lunarphobia, moon, predation, temperature

\begin{abstract}
Predation pressure, food availability, and activity may be affected by level of moonlight and climatic conditions. While many nocturnal mammals reduce activity at high lunar illumination to avoid predators (lunarphobia), most visually-oriented nocturnal primates and birds increase activity in bright nights (lunarphilia) to improve foraging efficiency. Similarly, weather conditions may influence activity level and foraging ability. We examined the response of Javan slow lorises (Nycticebus javanicus Geoffroy, 1812) to moonlight and temperature. We radio-tracked 12 animals in West Java, Indonesia, over 1.5 years, resulting in over 600 hours direct observations. We collected behavioural and environmental data including lunar illumination, number of human observers, and climatic factors, and 185 camera trap nights on potential predators. Nycticebus javanicus reduced active behaviours in bright nights. Although this might be interpreted as a predator avoidance strategy, animals remained active when more observers were present. We did not find the same effect of lunar illumination on two potential predators. We detected an interactive effect of minimum temperature and moonlight, e.g. in bright nights slow lorises only reduce activity when it is cold. Slow lorises also were more active in higher humidity and when it was cloudy, whereas potential predators were equally active across conditions. As slow lorises are well-adapted to avoid/defend predators by crypsis, mimicry and the possession of venom, we argue that lunarphobia may be due to prey availability. In bright nights that are cold, the combined effects of high luminosity and low temperature favour reduced activity and even torpor. We conclude that Javan slow lorises are lunarphobic - just as the majority of mammals.
\end{abstract}

\section{Contents}

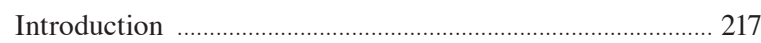

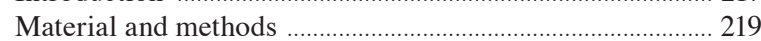

Statistical analysis ............................................................... 219

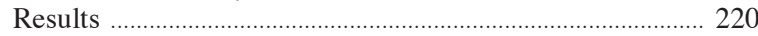

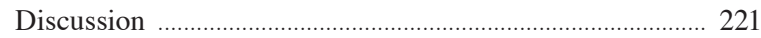

Lunar illumination and predation risk ........................ 221

Climatic factors ............................................................. 222

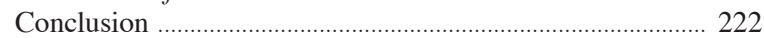

Acknowledgements .............................................................. 222

References ….............................................................................. 222

\section{Introduction}

To secure maintenance, survival and reproduction, animals adapt their behaviour to various factors, such as climate, availability of resources, competition, predation, luminosity, habitat fragmentation, and anthropogenic disturbance (Kappeler and Erkert, 2003; Beier 2006; Donati and Borgognini-Tarli, 2006). According to optimal foraging theory, animal behaviour can be seen as a trade-off between the risk of being preyed upon and the fitness gained from foraging (Charnov, 1976). Perceived predation risk assessed through indirect cues that correlate with the probability of encountering a predator may shape an animal's behaviour (Vasquez, 1994; Thorson et al., 1998; Orrock et al., 2004).

One of the indirect cues that animals use to assess predation risk is moonlight (Beier et al., 2006; Upham and Haffner, 2013). Most mammals decrease activity or change habitat choice with increasing lunar illumination (lunarphobia) (Price et al., 1984; Hecker et al., 1999; Horning and Trillmich, 1999; Nash, 2007; Penteriani et al., 2011; Saldaña-Vásquez and Munguía-Rosas 2013; Prugh and Golden, 2014) to be more concealed from predators. Some species increase their activity in brighter nights (lunarphilia) due to prey availability, higher foraging efficiency, or better visual detection of predators (Table 1; Horning and Trillmich, 1999; Packer et al., 2011; Prugh and Golden, 2014). Whether a species is lunarphobic or lunarphilic depends on the primary sensory system (e.g. visual acuity), phylogenetic relatedness, and habitat cover (Hecker et al., 1999; Michalski and Norris, 2011; Saldaña-Vásquez and MunguíaRosas, 2013; Prugh and Golden, 2014). Primates, for instance, are highly visually oriented (Gursky, 2003; Bearder et al., 2006) and are mainly lunarphilic, as opposed to rodents, lagomorphs carnivores and bats, which are largely lunarphobic (Prugh and Golden, 2014). Additionally to lunarphobia and lunarphilia, some species are lunarneutral, although the methods 
Table 1. Reactions of some animal species towards moonlight, and adaptive explanations. PA = predator avoidance, FA = food availablility, $\mathrm{FE}=$ foraging efficiency, $\mathrm{PD}=$ predator detection.

\begin{tabular}{|c|c|c|c|c|}
\hline Species & Scientific name & $\begin{array}{l}\text { Response to } \\
\text { lunar illumination }\end{array}$ & $\begin{array}{l}\text { Adaptive } \\
\text { explanation }\end{array}$ & References \\
\hline \multicolumn{5}{|l|}{ Predator avoidance } \\
\hline Kangaroo rat & Dipodomys sp. Gray, 1841 & Lunarphobic & PA & Upham and Haffner, 2013 \\
\hline Lesser bushbaby & Galago moholi Smith, 1836 & Lunarphilic & PA & Bearder et al., 2001; Bearder et al., 2006 \\
\hline \multicolumn{5}{|l|}{ Food availability } \\
\hline Galapagos fur seal & $\begin{array}{l}\text { Arctocephalus galapagoensis } \\
\text { Heller, } 1904\end{array}$ & Lunarphobic & FA, PA & $\begin{array}{l}\text { Trillmich and Mohren, 1981; } \\
\text { Horning and Trillmich, } 1999\end{array}$ \\
\hline Spectral tarsier & Tarsius spectrum Pallas, 1779 & Lunarphilic & FA, FE, PA & Gursky, 2007 \\
\hline \multicolumn{5}{|l|}{ Foraging efficiancy } \\
\hline Freckled nightjar & $\begin{array}{l}\text { Caprimulgus tristigma } \\
\text { Rueppell, } 1840\end{array}$ & Lunarphilic & $\mathrm{FE}$ & Ashdown and McKechnie, 2008 \\
\hline African lion & Panthera leo (Linnaeus, 1758) & Lunarphobic & FE & Packer et al., 2011 \\
\hline \multicolumn{5}{|l|}{ Predator detection } \\
\hline Common poorwill & $\begin{array}{l}\text { Phalaenoptilus nuttallii } \\
\text { (Audubon, 1844) }\end{array}$ & Lunarphilic & $\mathrm{PD}$ & Woods and Brigham, 2008 \\
\hline Male tree frogs & $\begin{array}{l}\text { Smilisca sila Duellman and } \\
\text { Trueb, } 1966\end{array}$ & Lunarphilic & $\mathrm{PD}$ & Tuttle and Ryan, 1982 \\
\hline
\end{tabular}

chosen may have an influence whether a certain reaction is found (Nash, 2007; Penteriani et al., 2011). The trade-offs regarding the reaction towards moonlight may vary between species, and even local populations (Lang et al., 2005; Saldaña-Vásquez and MunguíaRosas, 2013).

Weather condition is a second cue that may affect animal activity, causing variation in the detection of prey and predators, and influencing thermoregulation (Hanya, 2004). In general, low temperature causes animals - prey and predator species - to decrease activity to conserve energy. Low temperature especially affects the activity of poikilotherm species like amphibians or arthropods (Fitzgerald and Bider, 1974; Fadamiro and Wyatt, 1995) but also homeotherm species that may decrease activity, employ social and postural thermoregulation (Donati et al., 2011), or go into torpor or hibernation (Schmid, 2000; Dausmann et al., 2005; Schuelke and Ostner, 2007; Smit et al., 2011). Humidity and precipitation may affect animal activity. Strong rain or wind generally decrease insect availability and can impede the ability of predators to detect prey (Vickery and Bider, 1981; Thies et al., 2006). Some animals are more active in high humidity and precipitation due to food availability or physiological needs (amphibians: Fitzgerald and Bider, 1974; rodents: Orrock et al., 2004; insects: Fadamiro and Wyatt, 1995; arthropods: Skutel- sky, 1996), some decrease activity due to energetic constraints (primates: Donati and Borgognini-Tarli, 2006; bats: Voigt et al., 2011).

Asian lorises (Lorisinae) are characterized by a suite of morphological traits that makes them sensitive to predators, foraging and temperature. Both slow (the genus Nycticebus) and slender (the genus Loris) lorises are arboreal slow climbers (Crompton et al., 1993), and rely on crypsis to avoid predators. Nycticebus is venomous, a trait that has been attributed to predator defence (Alterman, 1995; Nekaris et al., 2013), which might also affect its activity. High susceptibility to predators suggests that lorises would more likely be lunarphobic. Data from the wild, however, do not follow a consistent pattern. Wild red slender loris Loris tardigradus (Linnaeus, 1758) tended to lower activity in bright nights, although this was not significantly different from dark night behaviour; they rested, groomed more and whistled more frequently during bright nights, but not significantly suggesting a certain reaction towards moon light (Bernede, 2009). Although in general grey slender lorises L. lydekkerianus Cabrera, 1908 were lunarneutral, they were in some aspects lunarphilic (Bearder $e t$ al., 2001, 2006), whistling more in bright nights, and foraging more for energy-rich insects (Bearder et al., 2001). Infants of L. lydekkerianus however, sought more habitat cover in bright nights, possibly as predator avoid- 
ance strategy, indicating lunarphobia for this age class (Bearder et al., 2001). In Cambodia, the pygmy loris (Nycticebus pygmaeus Bonhote, 1907) was lunarphobic, especially in cold nights (Starr et al., 2012). Rogers and Nekaris (2011) report that Bengal slow lorises (Nycticebus bengalensis Lacépède, 1800) in Cambodia become more active during the dark moon phase. During surveys of the Javan slow loris (N. javanicus Geoffroy, 1812) lunar neutrality was suggested in that moonlight had no impact on detectability of the species (Nekaris et al., 2014). Captive greater slow lorises (N. coucang [Boddaert, 1785]) reduced activity with higher illumination (Trent, 1977).

It is notable that in the single wild study with clear evidence of lunarphobia, Starr et al. (2012) found that decrease in activity was heightened during low temperatures. Lorisines have low metabolic rates, good fur insulation, and possess extensive vascular retia mirabilia that help them to stay inactive for prolonged periods (Whittow et al., 1977; Mueller, 1979). Most notably, Nycticebus spp. enter torpor for hours or days in cold temperatures (Nekaris and Bearder, 2011). Starr et al. (2012) proposed that the combined risk of both predation and heat loss outweigh the benefits of being active, and that temperature should be considered in further discussions of loris activity.

The Javan slow loris (Nycticebus javanicus), endemic to Java, Indonesia (Nekaris and Bearder, 2011), weighs around $1 \mathrm{~kg}$, is known to go into torpor, and occurs at least up to $1800 \mathrm{~m}$ above sea level (asl) (Nekaris et al., 2014; Nekaris and Rode-Margono, unpub. data). Indeed, much of the forest left on Java where slow lorises are found is at altitudes above $1000 \mathrm{~m}$ (Nekaris et al., 2014; Voskamp et al., 2014). We thus examined the effect of lunar illumination and temperature on activity of the Javan slow loris at a high altitude site replete with numerous potential predators. We also examined microhabitat use in the light of understanding predator perception.

\section{Material and methods}

We conducted our study on the foothills of the active volcano Papandayan in West Java. The site was located at altitudes ranging from $800-1800 \mathrm{~m}$ asl, ranging into Zones that are in Java classified as sub-montane (1200$1800 \mathrm{~m}$ asl) and Montane Zones (1600-2400 m asl); at altitudes above $1500 \mathrm{~m}$ asl, ground frost can occur (Nijman, 2013). The research site was located at S7 $6^{\prime} 6$ $7^{\circ} 7^{\prime} 0$ and E107 $46^{\prime} 0-107^{\circ} 46^{\prime} 5$ and consisted of a mo- saic-like landscape with forest and bamboo fragments (locally known as 'talun') and agricultural fields. Average temperature is relatively constant, but precipitation varies during the year, and daily minimum temperature ranges between $10.4^{\circ} \mathrm{C}$ and $20.7^{\circ} \mathrm{C}$.

We captured 12 animals by hand, took morphometric measurements, fitted a radio collar (ca. $17 \mathrm{~g}$, Biotrack, UK) and released the animal at the capture site. From April 2012 to June 2013, we followed animals in two shifts from 18:00 $\mathrm{h}$ to $0: 00 \mathrm{~h}$ and $00: 00 \mathrm{~h}$ to $6: 00 \mathrm{~h}$ (Wiens and Zitzmann, 2003) using antenna (6 and 8 element flexible Yagi antenna, Biotrack, UK) and receiver (R1000, Communication Specialists, US). We used instantaneous focal animal sampling with 5-minute intervals for behaviour and habitat data collection (Altmann, 1974). We followed the ethogram of Moore (2012) and grouped resting and sleeping into the category "not active" and all other behaviours except "other" into "active". We recorded the heights of the animal and used tree. Assuming that a higher position in the tree provides more concealment by the canopy, we used the relative height (height of the animal divided by height of the tree) of the animal's used tree as an indication of safety. We recorded any sighting of potential nocturnal predators, including common palm civets (Paradoxurus hermaphroditus [Pallas, 1777]) and leopard cats (Prionailurus bengalensis [Kerr, 1792]). Additionally, we had one to four camera traps (Cuddeback Attack IR; Bushnell Trophy cam night vision) installed in 185 nights (304 individual camera trap nights). Cameras were installed about $50 \mathrm{~cm}$ above the ground in relatively dense forest or bamboo patches with undergrowth, located within home ranges of radiotracked slow lorises. With a TFA Nexus weather station (TFA Dostmann, Germany) located at our basecamp, we collected data on temperature, humidity, rain and wind, with one data point every hour. We calculated minimum temperature of the night and rain over the last 24 hours. We estimated cloud cover in the field to the nearest $10 \%$. Luminosity was recorded using the exact percentage of the moon illuminated when above the horizon, using the programme MOONDV version 1 (Thomas, 1998). When below the horizon an illumination of 0 was recorded.

\section{Statistical analysis}

To increase independence of the data we used only every $6^{\text {th }}$ data point of our dataset, yielding single observations of the same individuals that were at least one hour apart. We excluded the first and last hour of the 
Table 2. Activity budget per hour for 12 adult Javan slow lorises, $\mathrm{n}=915$. Numbers shown in percentage. Data points were at least one hour apart.

\begin{tabular}{lcccccccccccccc}
\hline Hour of the night & 18 & 19 & 20 & 21 & 22 & 23 & 0 & 1 & 2 & 3 & 4 & 5 & Total \% Total N \\
\hline Feed and forage & 51.6 & 50.7 & 37.1 & 43.4 & 39.5 & 27.3 & 38.5 & 29.3 & 33 & 30.3 & 31 & 66.7 & 37.3 & 341 \\
Rest and sleep & 12.9 & 13.3 & 21 & 21.3 & 31.1 & 35.2 & 28.2 & 34.8 & 22.7 & 27.3 & 10.3 & 0 & 25 & 229 \\
Travel & 19.4 & 17.3 & 12.9 & 13.1 & 10.9 & 15.9 & 11.5 & 10.9 & 12.5 & 15.2 & 41.4 & 0 & 14.2 & 130 \\
Alert and freeze & 6.5 & 10.7 & 15.3 & 9.8 & 7.6 & 11.4 & 15.4 & 9.8 & 18.2 & 13.6 & 3.4 & 33.3 & 11.8 & 108 \\
Groom & 3.2 & 5.3 & 9.7 & 5.7 & 7.6 & 6.8 & 5.1 & 10.9 & 5.7 & 7.6 & 6.9 & 0 & 7.1 & 65 \\
Social activities & 6.5 & 1.3 & 0.8 & 2.5 & 2.5 & 1.1 & 0 & 3.3 & 5.7 & 1.5 & 6.9 & 0 & 2.4 & 22 \\
Other & 0 & 1.3 & 3.2 & 4.1 & 0.8 & 2.3 & 1.3 & 1.1 & 2.3 & 4.5 & 0 & 0 & 2.2 & 20 \\
\hline
\end{tabular}

night (18:00 to 19:00 and 05:00 to 06:00) to ensure that astronomical twilight is excluded from the data. Astronomical twilight is defined as the moon being $18^{\circ}$ below the horizon (Erkert, 2003). Twilight effects on activity may result in peaks at dawn and dusk and an overrepresentation of certain behaviours usually performed in these periods (Bearder et al., 2001; 2006; Erkert and Cramer, 2006). We applied a logistic regression model due to the non-normal distribution of our data (c.f. Starr et al., 2012). We used the binary dependent variable "active" and "not active" (Field, 2009). The predictor variables were sex, number of observers, luminosity, minimum nightly temperature, average humidity per night, wind, cloud cover, rain per hour and relative height of slow loris. Humans can be seen as predators (Charles-Dominique, 1977), and although we did not witness hunting of slow lorises for the pet trade in our study area it was reported for neighbouring villages and is generally common in West Java (Nekaris et al., 2009). We then applied a similar model to the presence of potential predators with one night where camera traps operated or direct observations were conducted as sample unit. For these data we used illumination of the night (number of hours the moon was visible multiplied by moon phase), and we excluded cloud cover. Days without observations or camera traps were excluded. We included an index of effort into the model, consisting of the number of teams observing per night weighted by two to account for a higher viewing angle, plus the number of camera traps working that night. For both models, none of the predictor variables correlated significantly above $\mathrm{r}^{2}=0.6$. We used the forced entry method as we had specific predictions about the model (Field, 2009). If the odds ratio of a factor is above 1 there is a positive relation between dependent and independent variable.

\section{Results}

We collected 7169 5-minute observation points of 12 radio-collared adult individuals, resulting in approximately 600 hours of direct observation and 1036 used data points. The activity budget of all animals per hour can be seen in Table 2. There was a significant relationship between activity and the different hours of the night $\left(\chi^{2}=22.708\right.$, df $\left.=9, p<0.007\right)$, with animals being less inactive than expected between 19:00 and 20:00.

The logistic regression model with slow loris activity as the outcome variable was highly significant $\left(\chi^{2}\right.$ $(1)=116.158, \mathrm{df}=11, \mathrm{p}<0.001 ; \mathrm{R} 2=0.148(\mathrm{Cox}$ and Snell), 0.213 (Nagelkerke)), with lunar luminosity (B = $-3.926 \pm 1.863, \mathrm{p}=0.035)$, humidity $(\mathrm{B}=0.039 \pm 0.018$, $\mathrm{p}=0.029)$, clouds $(\mathrm{B}=0.727 \pm 0.308, \mathrm{p}=0.018)$, relative height $(B=-3.957 \pm 0.492, p<0.001)$ and the interaction of minimum temperature and moon $(B=0.234 \pm 0.113$, $\mathrm{p}=0.038$ ) having significant effects on whether slow lorises are active or inactive. While luminosity and relative height have negative effects on activity, humidity and cloud cover have positive effects. The interaction of minimum temperature and moonlight showed that temperature affected activity during bright nights, but not dark nights. Slow lorises are more active when it is warmer. In dark nights they are equally active in warm and cold nights.

Camera trapping revealed six independent photos of the leopard cat, ten of the Javan ferret badger (Melogale orientalis [Horsfield, 1821]), and 14 of the common palm civet. The logistic regression model with predator presence as the outcome variable was not significant $\left(\chi^{2}(1)\right.$ $=12.523, \mathrm{df}=7, \mathrm{p}=0.085$ ).

Farmers reported to us that domestic dogs sometimes detected and cornered slow lorises. We have never observed any flight or freezing reaction of Javan slow 
lorises towards common palm civets or leopard cats. In contrast, we have witnessed a sub-adult feeding unperturbed by an adult male common palm civet within $5 \mathrm{~m}$ distance.

\section{Discussion}

\section{Lunar illumination and predation risk}

Our model on slow loris activity revealed a negative effect of lunar illumination and relative height on activity, a positive effect of humidity and cloud cover, and an interaction effect of lunar illumination and temperature. Activity was not affected by the number of people observing the slow lorises, neither was an interaction effect with luminosity detected. The predator model was not significant, thus the detection of predators was not affected by moonlight or any climatic factors.

Most primate species increase their activity with increasing lunar illumination (Gursky, 2003; Kappeler and Erkert, 2003; Bearder et al., 2006; Donati and Borgognini-Tarli, 2006; Fernandez-Duque and Erkert, 2006). This can be explained by the high visual orientation in primates and higher effectiveness of foraging and detection of potential predators in bright nights (Gursky, 2003). Instead of hiding in the dark, some lunarphilic primate species additionally use mobbing and warning calls to deter predators and warn conspecifics (Gursky, 2006; Fichtel, 2007; Nash, 2007; Eberle and Kappeler, 2008). In contrast, Javan slow lorises in our study seemed to reduce their activity in brighter nights, as was found for pygmy lorises (Starr et al., 2012), Bengal slow lorises (Rogers and Nekaris, 2011) and greater slow lorises (Trent, 1977). We can confirm lunarphobia for Javan slow lorises. Slow lorises thus resemble more the behaviour of other lunarphobic mammals (Prugh and Golden, 2014). This was explained by Starr et al. (2012) with the animals' anti-predator behaviour relying on crypsis and concealment, and may be enhanced by the relatively disturbed and open habitat at our study site.

Although lunarphobic, we did not find any evidence that activity of slow lorises could be negatively affected by human presence, neither was there any apparent relation with the behaviour of predators. Slow lorises did not engage in more active behaviour like foraging, feeding and travelling in higher and denser canopy, but in contrast are more active in lower heights. Confirmed predators of Nycticebus are orang-utans (Utami and van Hooff, 1997), snakes (Wiens and Zitzmann, 1999), hawk-eagles (Hagey et al., 2003), and monitor lizards (Kenyon et al., 2014). Although all of these taxa may not be sympatric with Javan slow lorises, adaptations to such predators may still be responsible for their behavioural responses (Goodman et al., 1993). The African potto (Perodicticus potto [Mueller, 1766]) is comparable to Javan slow lorises in size and ecology and is predated upon by viverrids of relatively small size and by domestic dogs (Canis lupus Linnaeus, 1758) (Nash, 2007; Nekaris et al., 2007); pottos showed reactions to viverrids in predation experiments (Charles-Dominique, 1977). Despite presence of potential predators, slow lorises did not show any fear when encountering potential non-human predators. Similar oblivious reactions to potential predators occurred in red and grey slender lorises and in greater slow lorises (Wiens, 2002; Nekaris et al., 2007). Although hunting is the main threat to Javan slow lorises (Nekaris et al., 2009; 2013), the number of observers had no effect on slow loris activity. Lorises may not fear people because they do not perceive people as predators or they are habituated due to the presence of local farmers.

One alternative explanation to predation pressure is a potential higher availability of prey during either moonlit or dark nights. Lang et al. (2005) attributed high activity during dark moon phases of the lunarphobic Neotropical insectivorous bat Lophostoma silvicolum Tomes, 1863 to high prey availability of katydids. Foraging depth of Galapagos fur seals (Arctocephalus galapagoensis Heller, 1904) followed the moonlightdependent horizontal migration of fish and squid (Horning and Trillmich 1999). The effect of insect abundance depends on the food preferences of the insectivorous predator. Although these data are not yet available for our field site, it is possible that the higher activity of slow lorises in dark nights follows the higher prey abundance; we are investigating this possibility with future studies.

We suggest that not predator avoidance but alternative factors like higher prey availability cause the slow loris to be more active in darker nights, perhaps due to the extreme morphological adaptations of lorises to avoid predators in the first place. Lorisines rely heavily on crypsis, moving slowly and freezing when feeling threatened (Nekaris et al., 2007). Their fur colour blends in with tree bark and makes animals difficult to detect (Nekaris et al., 2010). Slow lorises are among the few mammal species that are venomous (Alterman, 1995; Hagey et al., 2006; Ligabue-Braun et al., 2012; Nekaris et al., 2013). We are not aware of studies on other venomous mammals with a focus on the influence on 
moonlight on behaviour. Although uncommon in vertebrates (Pough, 1988), slow lorises may show Muellerian mimicry (Moore, 2012; Nekaris et al., 2013) with Indian cobras (Naja naja [Linnaeus, 1758]). Morphological and behavioural defences against predators can effectively reduce a prey's perception of risk (Stankowich and Blumenstein, 2005), and the combinations of slow lorises' adaptations might be effective enough to make them rather fearless animals when it comes to direct or indirect encounters with potential predators.

\section{Climatic factors}

Of the environmental factors, only humidity and cloudiness had a significant independent effect. Different effects of humidity on the activity of animals have been found (positive: Fitzgerald and Bider, 1974; Orrock et al., 2004; Skutelsky, 1996; negative: Kappeler and Erkert, 2003; Donati and Borgognini-Tarli, 2006). Slow lorises become more active with increasing humidity, possibly because of a higher availability of arthropod prey, which also become more active in higher humidity (Fadamiro and Wyatt, 1995). Swifts increase flight height in lower humidity, following flying insects that adapt their flying height to humidity (Shamoun-Baranes et al., 2006). Slow lorises include many flying insects like Coleoptera and Lepidoptera in their diet (Wiens et al., 2006; Starr and Nekaris, 2013). As slow lorises cannot leap or fly, they may be more actively foraging when humidity is high and insects fly low. Thus, we attributed the positive effect of higher humidity on activity to an adaptation to the activity of flying insect prey. Higher percentage of cloud cover contributes to the darkness that is favoured by Javan slow lorises. As the temperature at our study site can drop to about $10^{\circ} \mathrm{C}$, it is likely that temperature would have affected the activity of Javan slow lorises. Although we could not find an independent effect of temperature, we detected an interaction effect of luminosity and temperature in Javan slow lorises, just like for pygmy lorises (Starr et al., 2012). Indeed, during these inactive bouts, Javan slow lorises, like pygmy lorises, might not move for hours at a time. Many small endotherm species show heterothermy (Heldmaier and Ruf, 1992; Heldmaier et al., 2004), including several nocturnal primates such as lemurs of the family Cheirogaleidae and lesser bushbabies (Galago moholi Smith, 1836) (Schmid, 2000; Smit et al., 2011; Dausmann et al., 2005; Schuelke and Ostner, 2007; Nowak et al., 2010). Nycticebus spp. are able to enter torpor (Whittow et al., 1977; Xiao et al., 2010). We have already found evidence for torpor in one animal at our study site (Rode-Morgano and Nekaris, unpub. data) and we are further investigating through physiological measurement if animals at our site regularly enter torpor during cold temperatures. Just as for reaction towards moon light, the insignificant model for potential predators did not indicate an effect of climate factors on their activity.

\section{Conclusion}

Nash (2007) rightfully stressed that crypsis and predation are not unitary phenomena but interact in complex ways. Most primate species are lunarphilic, but slow lorises seem to be the exception from that rule and decrease activity in bright moonlight (lunarphobia) like most other mammals. A higher activity when cloud cover is higher may contribute to this behaviour. Javan slow lorises seem to be indifferent to potential predators and do not shift their activities into more covered habitat. We suggest that lunarphobia in slow lorises is not due to an increased perceived predator risk, but due to other factors like lower availability of prey species in moonlit nights. Additionally, slow lorises may be well-adapted to avoid or defend against predators by crypsis, venom and mimicry, and thus, do not need to be afraid in the dark.

\section{Acknowledgements}

We thank the authorities Riset and Teknologi (Ristek), Balai Konservasi Sumber Daya Alam Bandung (BKSDA Bandung), Research Center for Biology, Indonesian Institute of Sciences (LIPI) and Konservasi Sumber Daya Alam Garut (KSDA Garut) for their support in this project. This work was supported by the Leverhulme Trust (RPG-084), Mohamed bin Zayed Species Conservation Fund (12254023), People's Trust for Endangered Species, Conservation International Primate Action Fund, Cleveland Zoological Society and Cleveland Metroparks Zoo, Chicago Zoological Society / Chicago Board of Trade Endangered Species Fund, Primate Society of Great Britain Conservation Working Party, Columbus Zoo, Amersfoort Zoo, Primate Conservation Inc., ZGAP and International Primate Protection League. We thank the anonymous reviewers for their thorough and helpful comments.

\section{References}

Alterman L. 1995. Toxins and toothcombs: Potential allospecific chemical defenses in Nycticebus and Perodicticus. Pp. 413-424 in: Alterman L, Doyle GA, Izard MK, eds, Creatures of the dark: the nocturnal prosimians. New York: Plenum Press. 
Altmann J. 1974. Observational study of behaviour: sampling methods. Behaviour 49: 227-267.

Ashdown RA, McKechnie AE. 2008. Environmental correlates of Freckled Nightjar (Caprimulgus tristigma) activity in a seasonal, subtropical habitat. Journal of Ornithology 149: 615-619.

Audubon JJ. 1844. The Birds of America. Volume 7. New York and Philadelphia: Audubon and Chevalier.

Bearder SK, Nekaris KAI, Buzzell CA. 2001. Dangers in the night: Are some nocturnal primates afraid of the dark? Pp 21-43 in: Miller LE, eds, Eat or be eaten: Predator sensitive foraging among primates. Cambridge, UK: Cambridge University Press.

Bearder S, Nekaris KAI, Curtis D. 2006. A re-evaluation of the role of vision in the activity and communication of nocturnal primates. Folia Primatologica 77: 50-71.

Beier P. 2006. Effects of artificial night lighting on terrestrial mammals. Pp. 19-42 in: Rich C, Longcore T, eds, Ecological consequences of artificial night lighting. Washington, DC: Island Press.

Bernede L. 2009. A study of the social and behavioural ecology of the red slender loris (Loris tardigradus tardigradus) in Masmullah Proposed Forest Reserve, Sri Lanka. PhD thesis, Oxford Brookes University.

Boddaert P. 1785. Elenchus animalium. Sistens quadrupedia huc usque nota, eorumque varietalis. Volume 1. Rotterdam, Netherlands: Hake.

Bonhote JL. 1907. On a collection of mammals made by Dr. Vassal in Annam. Proceedings of the Zoological Society of London 77: 3-11.

Cabrera A. 1908. Sobre los loris, y en especial sobre la forma filipina. Boletin de la Real Sociedad de Historia Natural 8: 135-139.

Charles-Dominique P. 1977. Ecology and behaviour of nocturnal primates: Prosimians of equatorial West Africa. New York, US: Columbia University Press.

Charnov EL. 1976. Optimal foraging, the marginal value theorem. Theoretical Population Biology 9: 129-136.

Crompton RH, Sellers WI, Gunther MM. 1993. Energetic efficiency and ecology as selective factors in the saltatory adaptation of prosimian primates. Proceedings of the Royal Society: Biological Sciences 254: 41-45.

Dausmann KH, Glos J, Ganzhorn JU, Heldmaier G. 2005. Hibernation in the tropics: lessons from a primate. The Journal of Comparative Physiology B 175: 147-155.

Donati G, Borgognini-Tarli SM. 2006. Influence of abiotic factors on cathemeral activity: the case of Eulemur fulvus collaris in the littoral forest of Madagascar. Folia Primatologica 77: 104-122.

Donati G, Ricci E, Baldi N, Morelli V, Borgognini-Tarli SM. 2011. Behavioural thermoregulation in a gregarious lemur, Eulemur collaris: Effects of climatic and dietary-related factors. American Journal of Physical Anthropology 144: 355-364.

Duellman WE, Trueb L. 1966. The neotropical hylid frogs of the genus Smilisca. University of Kansas Publications Museum of Natural History 17: 281-375.

Eberle M, Kappeler PM. 2008. Mutualism, reciprocity, or kin selection? Cooperative rescue of a conspecific from a boa in a nocturnal solitary forager the gray mouse lemur. American Journal of Primatology 70: 410-414.

Erkert HG. 2003. Chronobiological aspects of primate research. Pp. 252-270 in: Setchell JM, Curtis DJ, eds, Field and labo- ratory methods in primatology. Cambridge, UK: Cambridge University Press.

Erkert HG, Cramer B. 2006. Chronobiological background to cathemerality: circadian rhy thms in Eulemur fulvus albifrons (Prosimii) and Aotus azarai boliviensis (Anthropoidea). Folia Primatologica 77: 87-103.

Fadamiro HY, Wyatt TD. 1995. Flight initiation by Prostephanus truncates in relation to time of day, temperature, relative humidity and starvation. Entomologia Experimentalis et Applicata 75: 273-277.

Fernandez-Duque E, Erkert HG. 2006. Cathemerality and lunar periodicity of activity rhythms in owl monkeys of the Argentinian Chaco. Folia Primatologica 77: 123-138.

Fichtel C. 2007. Avoiding predators at night: antipredator strategies in red-tailed sportive lemurs (Lepilemur ruficaudatus). American Journal of Primatology 69: 611-624.

Field A. 2009. Discovering statistics using SPSS. London, UK: Sage publications.

Fitzgerald GJ, Bider JR. 1974. Influence of moon phase and weather factors on locomotory activity in Bufo americanus. Oikos 25: 338-340.

Geoffroy SHE. 1812. Suite au tableau des quadrummanes. Second famille. Lemuriens. Strepsirrhini. Annales du Muséum National d'Histoire Naturelle 19: 156-170.

Goodman SM, O'Connor S, Langrand O. 1993. A review of predation on lemurs: implications for the evolution of social behavior in small, nocturnal primates. Pp. 51-66 in: Kappeler PM, Ganzhorn JU, eds, Lemur social systems and their ecological basis. New York, US: Springer.

Gray JE. 1841. A new genus of Mexican glirine Mammalia. Annals and Magazine of Natural History 1: 521-522.

Gursky S. 2003. Lunar philia in a nocturnal primate. International Journal of Primatology 24: 351-367.

Gursky S. 2006. Function of snake mobbing in spectral tarsiers. American Journal of Physical Anthropology 129: 601-608.

Hagey L, Fry B, Fitch-Snyder H. 2007. Talking defensively, a dual use for the brachial gland exudate of slow and pygmy lorises. Pp. 253-272 in: Gursky S, Nekaris KAI, eds, Primate anti-predator strategies. New York, US: Springer.

Hanya G. 2004. Seasonal variations in the activity budget of Japanese macaques in the coniferous forest of Yakushima: effects of food and temperature. American Journal of Primatology 63: 165-177.

Hecker K, Brigham R. 1999. Does moonlight change vertical stratification of activity by forest-dwelling insectivorous bats? Journal of Mammalogy 80: 1196-1201.

Heldmaier G, Ruf T. 1992. Body temperature and metabolic rate during natural hypothermia in endotherms. Journal of Comparative Physiology 162: 696-706.

Heldmaier G, Ortmann S, Elvert R. 2004. Natural hypometabolism during hibernation and daily torpor in mammals. Respiratory Physiology \& Neurobiology 141: 317-329.

Heller E. 1904. Mammals of the Galapagos Archipelago: Exclusive of the Cetacea. Proceedings of the Californian Academy of Sciences 3: 245.

Horning M, Trillmich F. 1999. Lunar cycles in diel prey migrations exert a stronger effect on the diving of juveniles than adult Galapagos fur seals. Proceedings of the Royal Society: Biological Sciences 266: 1127-1132. 
Horsfield T. 1821. XIV. Systematic Arrangement and Description of Birds from the Island of Java. Transactions of the Linnean Society of London 13: 133-200.

Kappeler PM, Erkert HG. 2003. On the move around the clock: correlates and determinants of cathemeral activity in wild red fronted lemurs (Eulemur fulvus rufus). Behavioural Ecology and Sociobiology 54: 359-369.

Kenyon M, Streicher U, Loung H, Tran T, Tran M, Vo B, Cronin A. 2014. Survival of reintroduced pygmy slow loris Nycticebus pygmaeus in South Vietnam. Endangered Species Research. doi: 10.3354/esr00607.

Kerr R. 1792. The Animal Kingdom, or Zoological System of the Celebrated Sir Charles Linnaeus. London, UK: Murray and Faulder.

Lacépède BGE. 1800. Classification des oiseaux et des mammifières. Séances des écoles normales, recueillies par des sténographes, et revues par les professeurs 9 (appendix): 1-86.

Lang AB, Kalko EK, Römer H, Bockholdt C, Dechmann DK. 2005. Activity levels of bats and katydids in relation to the lunar cycle. Oecologia 146: 659-666.

Ligabue-Braun R, Verli H, Carlini CR. 2012. Venomous mammals: A review. Toxicon 59: 680-695.

Linnaeus C. 1758. Systema naturae per regna tria naturae, secundum classes, ordines, genera, species, cum characteribus, differentiis, synonymis, locis. Tomus I. Editiodecima, reformata. Holmiae: Salvius.

Michalski F, Norris D. 2011. Activity pattern of Cuniculus paca (Rodentia: Cuniculidae) in relation to lunar illumination and other abiotic variables in the southern Brazilian Amazon. Zoologia (Curitiba) 28: 701-708.

Moore R. 2012. Ethics, ecology and evolution of Indonesian slow lorises (Nycticebus spp.) rescued from the pet trade. PhD thesis, Oxford Brookes University.

Mueller PLS. 1766. Pp. 12 (Supplements) in Linnaeus C. 1758. Systema naturae per regna trianaturae, secundum classes, ordines, genera, species, cum characteribus, differentiis, synonymis, locis. Tomus I. Editiodecima, reformata. Holmiae: Salvius.

Muller EF. 1979. Energy metabolism, thermoregulation and water budget in the slow loris (Nycticebus coucang, Boddaert 1785). Comparative Biochemistry and Physiology Part A 64: 109-119.

Nash LT. 2007. Moonlight and behaviour in nocturnal and cathemeral primates, especially Lepilemur leucopus: Illuminating possible anti-predator efforts. Pp. 173-205 in: Gursky S, Nekaris KAI, eds, Primate anti-predator strategies. New York, US: Springer.

Nekaris KAI, Jaffe S. 2007. Unexpected diversity of slow lorises (Nycticebus spp.) within the Javan pet trade: implications for slow loris taxonomy. Contributions to Zoology 76: 187-196.

Nekaris KAI, Bearder SK. 2011. The lorisiform primates of Asia and mainland Africa: Diversity shrouded in darkness. Pp. 34-54 in: Campbell CJ, Fuentes A, MacKinnon KC, Bearder SK, Stumpf RM, eds, Primates in perspective. 2 ed. Oxford, UK: Oxford University Press.

Nekaris KAI, Pimley ER, Ablard KM. 2007. Predator defense by slender lorises and pottos. Pp. 222-240 in: Gursky S, Nekaris KAI, eds, Primate anti-predator strategies. New York, US: Springer.
Nekaris KAI, Sanchez KL, Thorn JS, Winarti I, Nijman V. 2009. Javan slow loris. Pp. 44-46 in: Mittermeier RA, Wallis J, Rylands AB, Ganzhorn JU, Oates JF, Williamson EA, Palacios E, Heymann EW, Kierulff MCM, Yongcheng L, Supriatna J, Roos C, Walker S, Cortés-Ortiz L, Schwitzer S, eds, Primates in peril: The world's 25 most endangered primates 2008-2010. Arlington, VA: IUCN/SSC Primate Specialist Group (PSG), International Primatological Society (IPS), and Conservation International (CI).

Nekaris, KAI, Starr CR, Collins RL, Wilson A. 2010. Comparative ecology of exudate feeding by lorises (Nycticebus, Loris) and pottos (Perodicticus, Arctocebus). Pp 155-168 in: Burrows AM, Nash LT, eds, The Evolution of Exudativory in Primates. New York, US: Springer.

Nekaris KAI, Moore RS, Rode EJ, Fry BG. 2013. Mad, bad and dangerous to know: the biochemistry, ecology and evolution of slow loris venom. Journal of Venomous Animals and Toxins including Tropical Diseases 19: 21.

Nekaris KAI, Pambudi JAA, Susanto D, Ahmad RD, Nijman V. 2014. Densities, distribution and detectability of a small nocturnal primate (Javan slow loris Nycticebus javanicus) in a montane rainforest. Endangered Species Research 24: 95-103.

Nijman V. 2013. Distribution and ecology of the most tropical of the high-elevation montane colobines: the ebony langur on Java. Pp 115-132. In Gursky-Doyen S. et al., eds, High Altitude Primates. New York, US: Springer.

Nowak RM, Walker EP. 1999. Walker's Primates of the World. London, UK: Johns Hopkins University Press.

Orrock JL, Danielson BJ, Brinkerhoff RJ. 2004. Rodent foraging is affected by indirect, but not by direct, cues of predation risk. Behavioural Ecology 15: 433-437.

Packer C, Swanson A, Ikanda D, Kushnir H. 2011. Fear of darkness, the full moon and the nocturnal ecology of African lions. PloSone 6: e22285.

Pallas PS. 1777. Pp. 426 in Schreber JCD, ed., Die Säugethiere in Abbildungen nach der Natur mit Beschreibungen. Volume 3. Erlangen, Germany: Walthersche Kunst und Buchhandlung.

Penteriani V, Kuparinen A, Delgado MdM, Lourenço R, Campioni L. 2011. Individual status, foraging effort and need for conspicuousness shape behavioural responses of a predator to moon phases. Animal Behaviour 82: 413-420.

Pough FH. 1988. Mimicry of vertebrates: are the rules different? American Naturalist 131: S67-S102.

Price MV, Waser NM, Bass TA. 1984. Effects of moonlight on microhabitat use by desert rodents. Journal of Mammalogy 65: 353-356.

Prugh LR, Golden D. 2014. Does moonlight increase predation risk? Meta-analysis reveals divergent responses of nocturnal mammals to lunar cycles. Journal of Animal Ecology 83(2): 504-514.

Rogers LD, Nekaris KAI. 2011. Behaviour and habitat use of the Bengal slow loris Nycticebus bengalensis in the dry dipterocarp forests of Phnom Samkos Wildlife Sanctuary, Cambodia. Cambodian Journal of Natural History 2001: 104-112.

Rueppell E. 1840. NeueWirbelthierezu der Fauna von Abyssiniengehörig. Frankfurt, Germany: Schmerber.

Saldaña-Vázquez RA, Munguía-Rosas MA. 2013. Lunar phobia in bats and its ecological correlates: A meta-analysis. Mammalian Biology 78: 216-219. 
Schmid J. 2000. Daily Torpor in the Gray Mouse Lemur (Microcebus murinus) in Madagascar: Energetic Consequences and Biological Significance. Oecologia 123: 175-183.

Schuelke O, Ostner J. 2007. Physiological ecology of cheirogaleid primates: variation in hibernation and torpor. Acta Ethologica 10: 13-21.

Shamoun-Baranes J, Van Loon E, van Gasteren H, van Belle J, Bouten W, et al.2006. A comparative analysis of the influence of weather on the flight altitudes of birds. Bulletin of the American Meteorological Society 87: 47-61.

Skutelsky O. 1996. Predation risk and state-dependent foraging in scorpions: effects of moonlight on foraging in the scorpion Buthus occitanus. Animal Behaviour 52: 49-57.

Smit B, Boyles JG, Brigham RM, McKechnie AE. 2011. Torpor in dark times: patterns of heterothermy are associated with the lunar cycle in a nocturnal bird. Journal of Biological Rhythms 26: 241-248.

Smith A. 1836. Report of the Expedition for Exploring Central Africa from the Cape of Good Hope, June 23, 1834. Cape Town: Government Gazette Office.

Stankowich T, Blumstein DT. 2005. Fear in animals: a metaanalysis and review of risk assessment. Proceedings of the Royal Society: Biological Sciences 272: 2627-2634.

Starr C, Nekaris KAI, Leung L. 2012. Hiding from the moonlight: luminosity and temperature affect activity of Asian nocturnal primates in a highly seasonal forest. PloS one 7: e36396.

Starr C, Nekaris KAI. 2013. Obligate exudativory characterizes the diet of the pygmy slow loris Nycticebus pygmaeus. American Journal of Primatology 75: 1054-1061.

Thies W, Kalko EK, Schnitzler H-U. 2006. Influence of environment and resource availability on activity patterns of Carollia castanea (Phyllostomidae) in Panama. Journal of Mammalogy 87: 331-338.

Thomas RM. 1998. MoonDV software. Moon version 1.

Thorson JM, Morgan RA, Brown JS, Norman JE. 1998. Direct and indirect cues of predatory risk and patch use by fox squirrels and thirteen-lined ground squirrels. Behavioural Ecology 9: 151-157.

Tomes RF. 1863. On a new genus and species of leaf-nosed bat in the museum at Fort Pitt. Proceedings of the Zoological Society of London 1863:81-84.

Trent BK, Mary ET, Lockard JS. 1977. Activity changes with illumination in slow loris Nycticebus coucang. Applied Animal Ethology 3: 281-286.

Trillmich F, Mohren W. 1981. Effects of the lunar cycle on the Galapagos fur seal, Arctocephalus galapagoensis. Oecologia 48: 85-92.

Tuttle MD, Ryan MJ. 1982. The role of synchronized calling, ambient light, and ambient noise, in anti-bat-predator behaviour of a treefrog. Behavioural Ecology and Sociobiology 11: $125-131$.
Upham NS, Hafner JC. 2013. Do nocturnal rodents in the Great Basin Desert avoid moonlight? Journal of Mammalogy 94: 59-72.

Utami SS, Van Hooff JA. 1997. Meat-eating by adult female Sumatran orangutans (Pongo pygmaeus abelii). American Journal of Primatology 43: 159-165.

Vasquez RA. 1994. Assessment of predation risk via illumination level: facultative central place foraging in the cricetid rodent Phyllotis darwini. Behavioural Ecology and Sociobiology 34: 375-381.

Vickery W, Bider J. 1981. The influence of weather on rodent activity. Journal of Mammalogy 62: 140-145.

Voigt CC, Schneeberger K, Voigt-Heucke SL, Lewanzik D. 2011. Rain increases the energy cost of bat flight. Biology letters 7: 793-795.

Voskamp A, Rode EJ, Coudrat CNZ, Wirdateti, Abinawanto, Wilson RJ, Nekaris KAI. 2014. Modelling the habitat use and distribution of the threatened Javan slow loris Nycticebus javanicus. Endangered Species Research 23: 277-286.

Whittow G, Scammell C, Manuel JK, Rand D, Leong M. 1977. Temperature regulation in a hypometabolic primate, the slow loris (Nycticebus coucang). Archives of Physiology and Biochemistry 85: 139-151.

Wiens F. 2002. Behaviour and ecology of wild slow lorises (Nycticebus coucang): social organization, infant care system, and diet. PhD dissertation. University of Bayreuth: Bayreuth, Germany.

Wiens F, Zitzmann A. 1999. Predation on a Wild Slow Loris (Nycticebus coucang) by a Reticulated Python (Python reticulatus). Folia Primatologica 70: 362-364.

Wiens F,Zitzmann A. 2003. Social structure of the solitary slow loris Nycticebus coucang (Lorisidae). Journal of Zoology 261: 35-46.

Wiens F, Zitzmann A, Hussein NA. 2006. Fast food for slow lorises: is low metabolism related to secondary compounds in high-energy plant diet? Journal of Mammalogy 87: 790798.

Woods CP, Brigham RM. 2008. Common poorwill activity and calling behaviour in relation to moonlight and predation. Wilson Journal of Ornithology 120: 505-512.

Xiao C, Wang Z, Zhu W, Chu Y, Liu C, Jia T, Meng L, Cai J. 2010. Energy metabolism and thermoregulation in pygmy lorises (Nycticebus pygmaeus) from Yunnan Daweishan Nature Reserve. Acta Ecologica Sinica 30: 129-134.

Received: 11 February 2014

Revised and accepted: 14 July 2014

Published online: 5 September 2014

Editor: V. Nijman 